\title{
TRAP transporters: an ancient family of extracytoplasmic solute-receptor-dependent secondary active transporters
}

\author{
Ralf Rabus, ${ }^{1} \dagger$ Donald L. Jack, ${ }^{1}$ David J. Kelly ${ }^{2}$ and Milton H. Saier, Jr ${ }^{1}$ \\ Author for correspondence: Milton H. Saier, Jr. Tel: +1 619534 4084. Fax: +1 6195347108. \\ e-mail:msaier@ucsd.edu
}

1 Department of Biology, University of California at San Diego, La Jolla, CA, 92093-0116, USA

2 Krebs Institute, Department of Molecular Biology and Biotechnology, University of Sheffield, Sheffield S10 2UH, UK

\begin{abstract}
Tripartite ATP-independent periplasmic transporters (TRAP-T) represent a novel type of secondary active transporter that functions in conjunction with an extracytoplasmic solute-binding receptor. The best characterized TRAP-T family member is from Rhodobacter capsulatus and is specific for $\mathrm{C}_{4}$-dicarboxylates [Forward, J. A., Behrendt, M. C., Wyborn, N. R., Cross, R. \& Kelly, D. J. (1997). $J$ Bacteriol 179, 5482-5493]. It consists of three essential proteins, DctP, a periplasmic $\mathrm{C}_{4}$-dicarboxylate-binding receptor, and two integral membrane proteins, DctM and DctQ, which probably span the membrane 12 and 4 times, respectively. Homologues of DctM, DctP and DctQ were identified in all major bacterial subdivisions as well as in archaea. An orphan DctP homologue in the Gram-positive bacterium Bacillus subtilis may serve as a receptor for a twocomponent transcriptional regulatory system rather than as a constituent of a TRAP-T system. Phylogenetic data suggest that all present day TRAP-T systems probably evolved from a single ancestral transporter with minimal shuffling of constituents between systems. Homologous TRAP-T constituents exhibit decreasing degrees of sequence identity in the order DctM $>$ DctP $>$ DctQ. DctM appears to belong to a large superfamily of transporters, the ion transporter (IT) superfamily, one member of which can function by either protonmotive force- or ATP-dependent energization. It is proposed that IT superfamily members exhibit the unusual capacity to function in conjunction with auxiliary proteins that modify the transport process by providing (i) highaffinity solute reception, (ii) altered energy coupling and (iii) additional yet to be defined functions.
\end{abstract}

Keywords: ion transport, dicarboxylates, TRAP-T family, phylogeny, molecular evolution

\section{INTRODUCTION}

All organisms use transport systems to facilitate the vectorial movement of nutrients and other solutes across biological membranes. Based on molecular architecture and the energy used to drive transport, five types of transport systems have been distinguished (Fig. 1; Nikaido \& Saier, 1992) : (i) facilitators (Fig. 1a) mediate

† Present address: MPI für marine Mikrobiologie, Celsiustr. 1, D-28359 Bremen, Germany.

Abbreviations: gb, GenBank; IT, ion transporter; p.m.f., protonmotive force; sp, SWISS-PROT; TC, transport classification; TMS, transmembrane spanning $\alpha$-helix; TRAP-T, tripartite ATP-independent periplasmic transporters. facilitated diffusion but are incapable of substrate accumulation; (ii) secondary active transporters (Fig. 1b) couple substrate translocation to the downhill influx of $\mathrm{H}^{+}$or $\mathrm{Na}^{+}$(Maloney, 1994; Maloney \& Wilson, 1996); (iii) primary active transporters (Fig. 1d) are energized by the utilization of a primary source of energy such as ATP, and one type of these systems, the ATP-binding cassette $(\mathrm{ABC})$ uptake permeases of prokaryotes, employ high-affinity extracytoplasmic solutebinding proteins (Ames, 1986; Boos \& Lucht, 1996; Higgins, 1992); (iv) group-translocators of the phosphoenolpyruvate (PEP): sugar phosphotransferase system (PTS) (Fig. 1e) couple sugar translocation to PEPdependent sugar phosphorylation (Postma et al., 1993); (v) tripartite ATP-independent periplasmic transporters 
(a)

$$
\text { Periplasm }
$$

\section{Cytoplasmic}

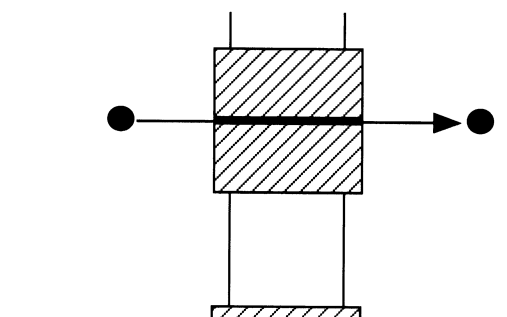

(b)

(c)

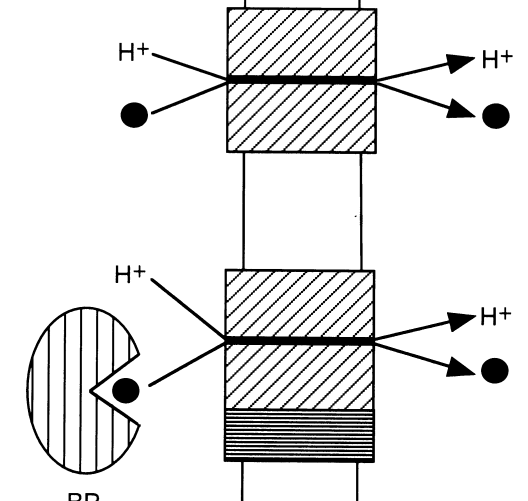

(d)

BP

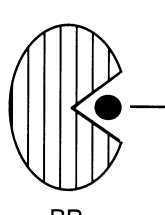

(e)

$\mathrm{BP}$

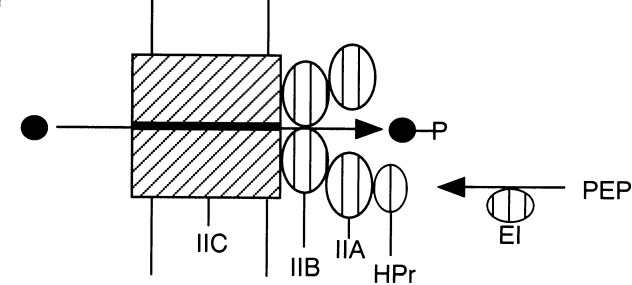

Fig. 1. Models of recognized classes of transporters. (a) Facilitator, (b) secondary transporter, (c) TRAP transporter, (d) binding-protein-dependent ABC-type transporter, (e) phosphotransferase system. BP, binding protein; filled circles, solute to be translocated. Modified from Nikaido \& Saier (1992).

(TRAP-T; Fig. 1c), only recently discovered, employ a periplasmic binding protein as do $\mathrm{ABC}$ uptake permeases, but they use the protonmotive force (p.m.f.) as a source of energy (Forward et al., 1997).

Many secondary active transport proteins exhibit a common transmembrane topology of $6+6=12$ transmembrane spanning $\alpha$-helices (TMSs; Nikaido \& Saier, 1992). Recently, a new classification system, the transport classification (TC) system, has been proposed (Saier, 1998) which integrates function and phylogeny for classifying the immense diversity of transport systems found in nature (see our transport classification web site: http://www-biology.ucsd.edu/ msaier/ transport/titlepage.html). Carrier-type facilitators (TC no. 2) and ATP-driven active transporters (TC no. 3),

are among the twelve primary categories of transport systems recognized in the TC system.

As noted above, ATP-driven uptake systems of the ABC superfamily (Ames, 1986; Higgins et al., 1990; Saier, 1998) function in conjunction with periplasmic solutebinding receptors that release the solute to the integral membrane translocator (Boos \& Lucht, 1996; Higgins et al., 1990; Hyde et al., 1990; Fig. 1d), and equivalent receptors are essential constituents of TRAP-T systems. These systems have been shown to be specific for $\mathrm{C}_{4}$ dicarboxylates in Rhodobacter capsulatus (Forward et al., 1997; Shaw et al., 1991; Shaw \& Kelly, 1991) or glutamate in Rhodobacter sphaeroides (Jacobs et al., 1996). The former system is encoded within the $\operatorname{dct} P Q M$ operon (Forward et al., 1997; Hamblin et al., 1990) where DctP is the periplasmic $\mathrm{C}_{4}$-dicarboxylate-binding protein $\left(M_{\mathrm{r}} 36128\right)$, DctQ is a small integral membrane protein $\left(M_{\mathrm{r}} 24763\right)$ with 4 putative TMSs and DctM is a large integral membrane protein $\left(M_{r} 46827\right)$ with 12 putative TMSs. Insertional mutagenesis of any one of the three $d c t$ genes results in complete loss of p.m.f.dependent transport activity (Forward et al., 1997). Glutamate uptake in Rhodobacter sphaeroides, which is dependent on a glutamate-binding protein, is also driven by the p.m.f. (Jacobs et al., 1996).

In the present study we identified all DctP, DctQ and DctM homologues in the current databases and conducted phylogenetic analyses on representative TRAP-T protein constituents. We thus define the three families of functionally related proteins that presumably comprise TRAP-T systems. Phylogenetic analyses lead to the conclusion that such systems are ancient, and that all currently identified systems probably arose from a single primordial system with little or no shuffling of constituents between them. In Bacillus subtilis, an organism with a completely sequenced genome, a DctP homologue may function independently of DctQ and DctM homologues as a transcriptional sensor. TRAP-T DctP proteins are proposed to be homologous to extracytoplasmic solute-binding receptors of $\mathrm{ABC}$ uptake systems. We provide evidence that DctM is a member of a large superfamily of ion transporters and suggest that members of this superfamily have the unusual capacity to associate with auxiliary proteins in order to modify their transport characteristics. Some of the data on which our conclusions are based are included on our phylogenetic web site (http://wwwbiology.ucsd.edu/ msaier/phylo/titlepage.html) rather than in the text of this paper. This site will be referred to as the Phylo web site in the text.

\section{COMPUTER METHODS}

Protein and translated nucleotide databases were screened using the FASTA (Pearson \& Lipman, 1988), BLAST (Altschul et al., 1990) and PSI-BLAST (Altschul et al., 1997) programs. The statistical significance of sequence similarities between putative members of the various families was established using the RDF2 (Pearson \& Lipman, 1988) and GAP (Devereaux et al., 1984) programs with 500 random shuffles. Binary comparison scores are expressed in standard deviations (SD; Dayhoff et al., 
Table 1. Members of the DctP family

\begin{tabular}{|c|c|c|c|c|}
\hline Abbreviation & Name or description in database & Organism & $\begin{array}{c}\text { Size } \\
\text { (no. of residues) }\end{array}$ & $\begin{array}{l}\text { Database and } \\
\text { accession no. }\end{array}$ \\
\hline DctP Rca & $\mathrm{C}_{4}$-dicarboxylate-binding periplasmic protein & Rhodobacter capsulatus & 333 & spP37735 \\
\hline DctP Rsp & $\mathrm{C}_{4}$-dicarboxylate-binding periplasmic protein & Rhodobacter sphaeroides & 337 & gbAF005842 \\
\hline SmoM Rsp & Periplasmic mannitol-binding protein & Rhodobacter sphaeroides & 365 & gbAF018073 \\
\hline Y146 Hin & $\begin{array}{l}\text { Hypothetical protein HI0146 precursor (strain } \\
\text { Rd KW20) }\end{array}$ & Haemophilus influenzae & 329 & spP44542 \\
\hline Y052 Hin & Hypothetical protein HI0052 precursor & Haemophilus influenzae & 328 & spP71336 \\
\hline YiaO Hin & Hypothetical protein HI1028 precursor & Haemophilus influenzae & 328 & spP44992 \\
\hline YiaO Eco & $\begin{array}{l}\text { Hypothetical } 36.0 \mathrm{kDa} \text { protein precursor in } \\
\text { avt } A-\text { selB intergenic region }\end{array}$ & Escherichia coli & 328 & spP37676 \\
\hline Y4mM Rsp & Hypothetical $57 \cdot 1 \mathrm{kDa}$ protein $\mathrm{Y} 4 \mathrm{mM}$ & $\begin{array}{l}\text { Rhizobium sp. strain } \\
\text { NGR234 }\end{array}$ & 541 & spP55572 \\
\hline Orf1 Ssp & $\begin{array}{l}\text { Putative } \mathrm{C}_{4} \text {-dicarboxylate binding protein } \\
\text { (Orf-ID sll1314) }\end{array}$ & $\begin{array}{l}\text { Synechocystis sp. strain } \\
\text { PCC } 6803\end{array}$ & 369 & gbD90907 \\
\hline Orf2 Ssp & Hypothetical protein (Orf-ID slr1962) & $\begin{array}{l}\text { Synechocystis sp. strain } \\
\text { PCC } 6803\end{array}$ & 370 & gbD90912 \\
\hline Orf279 Bpe & $\begin{array}{l}\text { Similar to } \mathrm{C}_{4} \text {-dicarboxylate-binding periplasmic } \\
\text { protein of } \mathrm{Rca}\end{array}$ & Bordetella pertussis & 280 & Not available* \\
\hline Orf Bsu & $\begin{array}{l}\text { Similar to } \mathrm{C}_{4} \text {-dicarboxylate-binding periplasmic } \\
\text { protein of } \mathrm{Rca}\end{array}$ & Bacillus subtilis & 350 & gbAB001488 \\
\hline DctP Ral & Hypothetical protein; similar to $\mathrm{YiaO}$ & Ralstonia sp. strain TFD41 & 209 & gbAF045553 \\
\hline DctP Wsu & $\begin{array}{l}\text { Putative } \mathrm{C}_{4} \text {-dicarboxylate periplasmic binding } \\
\text { protein precursor }\end{array}$ & Wolinella succinogenes & 329 & gbAJ132740 \\
\hline DctP Tma & $\begin{array}{l}\text { Putative periplasmic substrate-binding protein } \\
\text { precursor }\end{array}$ & Thermotoga maritima & 336 & gbAE001714 \\
\hline $\operatorname{DctP}_{1} \mathrm{Pae}$ & Hypothetical protein & Pseudomonas aeruginosa & 411 & Not available $\dagger$ \\
\hline $\operatorname{DctP}_{2} \mathrm{Pae}$ & Hypothetical protein & Pseudomonas aeruginosa & 331 & Not available $\dagger$ \\
\hline $\mathrm{DctP}_{3} \mathrm{Pae}$ & Hypothetical protein & Pseudomonas aeruginosa & 346 & Not available $\dagger$ \\
\hline $\mathrm{DctP}_{4} \mathrm{Pae}$ & Hypothetical protein & Pseudomonas aeruginosa & 332 & Not available $\dagger$ \\
\hline Orf $_{1}$ Afuł & Hypothetical protein (AF0635) & Archaeoglobus fulgidus & 330 & gbAE001060 \\
\hline $\mathrm{Orf}_{2}$ Afu & Hypothetical protein (AF0467) & Archaeoglobus fulgidus & 355 & gbAE001072 \\
\hline $\mathrm{Orf}_{3}$ Afuł & Hypothetical protein (AF0998) & Archaeoglobus fulgidus & 347 & gbAE001036 \\
\hline
\end{tabular}

*Forward et al. (1997).

† Kindly provided by PathoGenesis Inc. (Seattle, USA) prior to publication.

¥ The three Orfs of Archaeoglobus fulgidus lack significant sequence similarity to the bacterial DctP homologues, but they (1) map adjacent to the three genes encoding the putative $\operatorname{Dct}(\mathrm{Q}) \mathrm{M}$ homologues, and (2) exhibit significant sequence and motif similarity with the glutamine- and glutamate-binding proteins of Escherichia coli.

1983). A value of 9 SD (probability that the observed degree of sequence similarity occurred by chance is $\left\langle 10^{-19}\right.$ ) is deemed sufficient to establish homology when this value is obtained for two aligned sequences of at least 60 residues in comparable portions of the proteins (Saier, 1994).

Multiple sequence alignments were constructed and phylogenetic analyses were performed using the TREE program (Feng \& Doolittle, 1990) and the Clustal $x$ program (Thompson et al., 1997). In order to correctly align the DctP, DctQ and DctM family proteins using the TREE program, $\mathrm{N}$-and C-terminal extensions of non-homology found in some or all of the homologues were artificially removed. Mean hydropathy and mean similarity analyses were conducted for all protein families analysed based on the resultant multiple alignments of the protein members of these families. Wellconserved portions of the alignments generated with the TREE program, and the complete alignments generated with the
Clustal x program, are presented on our Phylo web site (see Introduction). Multiple alignments and bootstrapped phylogenetic trees (Felsenstein, 1985) of the DctP, DctM and DctQ family proteins obtained using the CLUSTAL $\mathrm{x}$ program can also be found on this web site. Differences between the trees generated with the TREE and the CLUSTAL $x$ programs primarily reflect the different assumptions upon which these programs are based (Young et al., 1999). Bootstrapping, applied to the trees derived by use of the latter program, do not evaluate these assumptions and therefore do not provide a true measure of confidence as discussed previously (Young et al., 1999).

Mean hydropathy, similarity and amphipathicity plots were generated using a sliding window of 21 residues (Le et al., 1999). The hydropathy values described by Kyte \& Doolittle (1982) were used in the first of these three analyses. Motif searches were conducted using the MEME and MAST programs 
(Bailey \& Gribskov, 1998; Grundy et al., 1997) and signature sequences were defined according to Bairoch et al. (1997). All signature sequences were screened against the SWISS-PROT and TREMBL databases. Protein abbreviations used in this study as well as accession numbers which allow easy access to the sequences and primary references are provided in Tables $1-3$.

\section{RESULTS}

As noted above, TRAP-T of Rhodobacter capsulatus consists of three essential non-homologous proteins, DctP, DctQ and DctM. Homologues of each of these proteins were identified using the search methods described under Computer Methods and analysed as described below.

\section{The DctP family}

Table 1 lists established proteins of the DctP family. Twelve of the twenty-two proteins (those above the dashed line in Table 1) were used for the reported analyses. All family members analysed, with the exception of the Bacillus subtilis Orf, were from Gramnegative bacteria. In several organisms, multiple DctP homologues were found, and in these cases, the paralogues were found to be highly divergent. Three paralogues are encoded within the complete genome of Haemophilus influenzae, and two paralogues were found in Synechocystis sp. strain PCC6803 and in Rhodobacter sphaeroides. Interestingly, the two DctP paralogues in Rhodobacter sphaeroides exhibit different substrate-binding specificities with DctP Rsp shown to bind $\mathrm{C}_{4}$-dicarboxylates (M. D. Omrani \& D. J. Kelly, unpublished data) and SmoM Rsp proposed to function as a mannitol-binding protein (GenBank accession number AAC45772). An unsequenced glutamate-binding protein has been proposed to be a constituent of a TRAP-T system in this same organism (Jacobs et al., 1996). Members of the DctP family are generally of similar sizes, ranging from 280 to 350 amino acyl residues with the exception of Y $4 \mathrm{mM}$ from $R$ hizobium sp. strain NGR234, which is much larger, having 541 residues. This protein proved to be a fused DctP-DctQ homologue, and consequently the two domains were artificially spliced apart for the reported analyses.

Fig. 2 presents mean hydropathy (a) and mean similarity (b) plots for the 12 analysed N-terminally truncated members of the DctP family. The mean hydropathy plot revealed that DctP family members are hydrophilic with two distinct regions showing partial hydrophobic character (from alignment positions 80-110 and from positions 180-200). The latter region and the adjacent hydrophilic region (positions 200-220) show the highest percentage similarity. The poorly conserved N-terminal leader sequences of these proteins were removed to facilitate correct alignment of the proteins as indicated in the Computer Methods section.

Fig. 2(c) presents a phylogenetic tree of DctP family members derived using the TREE program of Feng $\&$
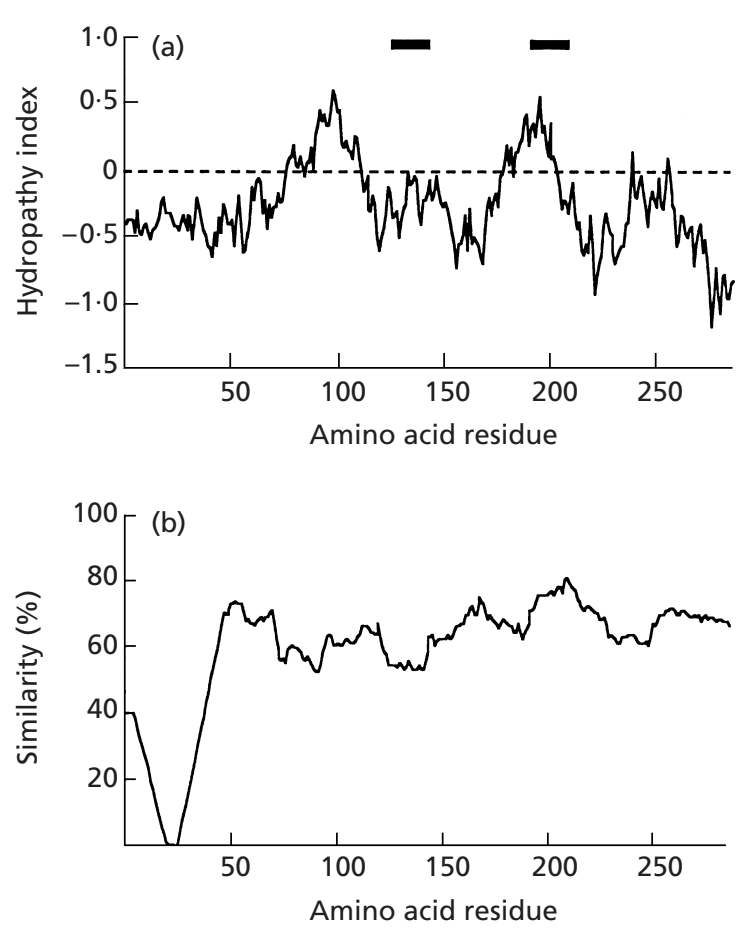

(c)

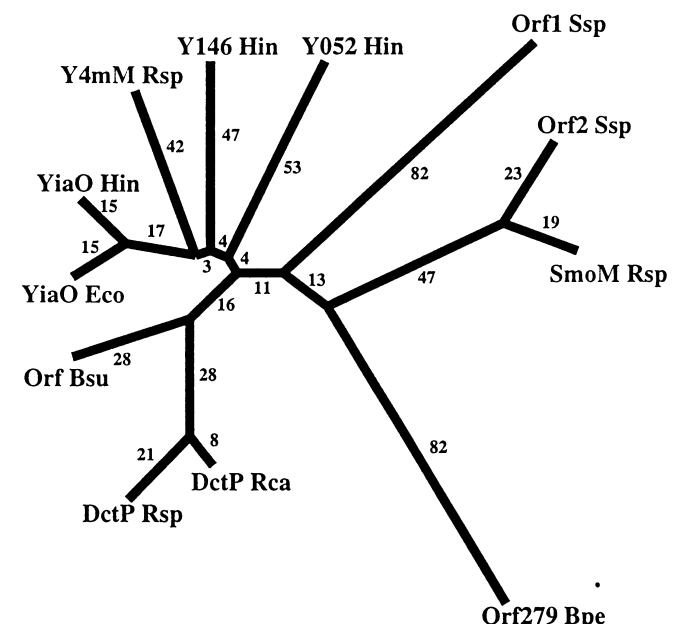

Fig. 2. Mean hydropathy plot (a), mean similarity plot (b) and phylogenetic tree (c) for the DctP family. The black bars in (a) indicate the portions of the multiple alignment that are presented on our Phylo web site. These plots were based on a multiple alignment of truncated sequences lacking the $\mathrm{N}$ terminal, poorly conserved hydrophobic signal sequence. The TREE program was used to generate the alignment as well as the tree. The configurations of this and other phylogenetic trees reported in this paper were confirmed using the CLUSTAL $X$ program with bootstrapping, and the results are presented on our Phylo web site (see Computer Methods). The abbreviations used in (c) are explained in Table 1.

Doolittle (1990). The tight clustering and short branch lengths connecting some members from dissimilar bacterial species reflect their high degrees of sequence similarity and indicate that these proteins are 
Table 2. Members of the DctQ family

\begin{tabular}{|c|c|c|c|c|}
\hline Abbreviation & Name or description in database & Organism & $\begin{array}{c}\text { Size } \\
\text { (no. of residues) }\end{array}$ & $\begin{array}{l}\text { Database and } \\
\text { accession no. }\end{array}$ \\
\hline DctQ Rca & $\begin{array}{l}\text { Small integral membrane transport } \\
\text { protein }\end{array}$ & Rhodobacter capsulatus & 227 & gbX63974 \\
\hline Orf Rsp & $\begin{array}{l}\text { Similar to DctQ of Rhodobacter } \\
\text { capsulatus }\end{array}$ & Rhodobacter sphaeroides & 228 & gbAF005842 \\
\hline Y147 Hin & Hypothetical protein HI0147 & Haemophilus influenzae & 633 & spP44543 \\
\hline Y051 Hin & Hypothetical protein HI0051 & Haemophilus influenzae & 165 & spP44484 \\
\hline YiaM Hin & Hypothetical protein HI1030 & Haemophilus influenzae & 161 & spP44994 \\
\hline YiaM Eco & $\begin{array}{l}\text { Hypothetical } 17.5 \mathrm{kDa} \text { protein in } \\
\text { avt } A-\text { selB intergenic region }\end{array}$ & Escherichia coli & 157 & spP37674 \\
\hline Y4mM Rsp & Hypothetical $57 \cdot 1 \mathrm{kDa}$ protein $\mathrm{Y} 4 \mathrm{mM}$ & $\begin{array}{l}\text { Rhizobium sp. strain } \\
\text { NGR234 }\end{array}$ & 541 & spP55572 \\
\hline Orf Ssp & Hypothetical protein (Orf-ID sll1102) & $\begin{array}{l}\text { Synechocystis sp. strain } \\
\text { PCC } 6803\end{array}$ & 179 & gbD90913 \\
\hline DctQ Ral & Hypothetical protein, similar to YiaM & Ralstonia sp. strain TFD41 & 185 & gbAF045553 \\
\hline $\mathrm{DctQ}_{1} \mathrm{Pae}$ & Hypothetical protein & Pseudomonas aeruginosa & 210 & Not available* \\
\hline $\mathrm{DctQ}_{2} \mathrm{Pae}$ & Hypothetical protein & Pseudomonas aeruginosa & 217 & Not available* \\
\hline $\mathrm{DctQ}_{3} \mathrm{Pae}$ & Hypothetical protein & Pseudomonas aeruginosa & 164 & Not available* \\
\hline
\end{tabular}

* Kindly provided by PathoGenesis Inc. (Seattle, USA) prior to publication.

orthologues, having arisen by speciation. Interestingly, the three DctP paralogues of Haemophilus influenzae, Y146, YiaO and Y052, do not cluster, suggesting that they diverged from each other early in evolutionary history. The most divergent members of the family are Orf279 of Bordetella pertussis and Orf1 of Synechocystis sp. strain PCC6803.

A phylogenetic tree for the DctP family was also derived using the CLUSTAL X program, and bootstrapping was applied in order to evaluate the reliability at each node. This tree (and the corresponding bootstrapped trees for the DctQ and DctM family proteins) are presented on our Phylo web site (see Introduction for address). As expected, the results confirmed the reliability of nodes more distant from the centre of the unrooted tree but revealed a lesser degree of reliability for branch points near the centre.

Short but well-conserved and gap-free portions of the complete multiple alignment upon which the plots and tree shown in Fig. 2 were based are presented on our Phylo web site. From one of these alignments, a potential signature sequence for the DctP family was derived:

[SANF]-[RKNSQ]X2-[LIV]-x(2)-[LIVWPF]-[ADES][DHE]-[LIVMF]-X-G-[LQM]-[KRD]-[LIVM]-R[LIVTA]

$(\mathrm{x}=$ any residue; alternative residues at any position are presented in square brackets)

This signature sequence was screened against the SWISSPROT and TREMBL databases and was found to retrieve only members of the DctP family. By these criteria, it is thus a bona fide signature sequence and can be used to identify sequences of new members of the DctP family as they become available.

\section{The DctQ family}

Table 2 lists proteins that make up the DctQ family. Eight protein members (Table 2, above the dashed line) were included in our analyses. Three DctQ paralogues were found in Haemophilus influenzae. No DctM or DctQ homologue could be found in Bacillus subtilis although a DctP homologue is present in this organism (see Discussion). The sizes of DctQ family members range from 161 to 228 amino acyl residues with the exceptions of Y147 of Haemophilus influenzae and Y4 mM of Rhizobium sp. strain NGR234, which are larger due to fusion with other TRAP-T family constituents (DctM and DctP homologues, respectively). The $\mathrm{C}$ - and N-terminal regions of these proteins, respectively, were truncated in order to eliminate the non-DctQ homologous regions.

Fig. 3 presents mean hydropathy (a) and mean similarity (b) plots for the eight analysed members of the DctQ family. The mean hydropathy plot reveals four putative TMSs with greatest sequence similarity between residue positions 80 and 100 . The portion of the multiple alignment indicated by the bar in Fig. 3(a) is presented on our Phylo web site.

Fig. 3(c) presents the DctQ family phylogenetic tree. Implications of clustering and branch length have been discussed above for the DctP family. The Rhodobacter orthologues, DctQ Rca and Orf Rsp, associate in a tight cluster as seen in the DctP family. The three DctQ 

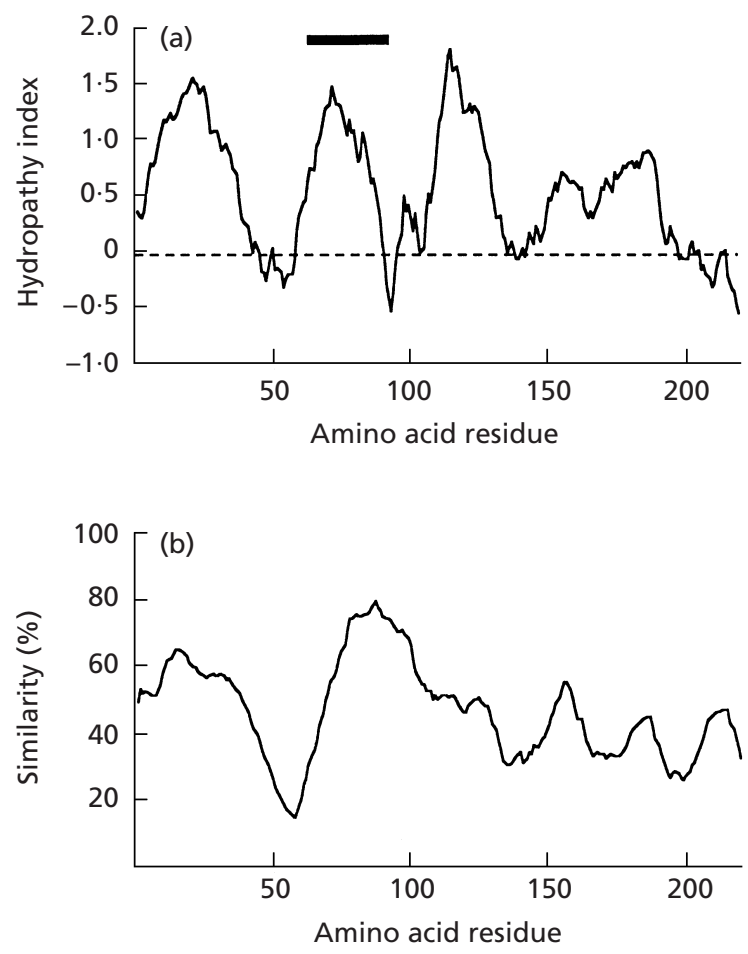

(c)

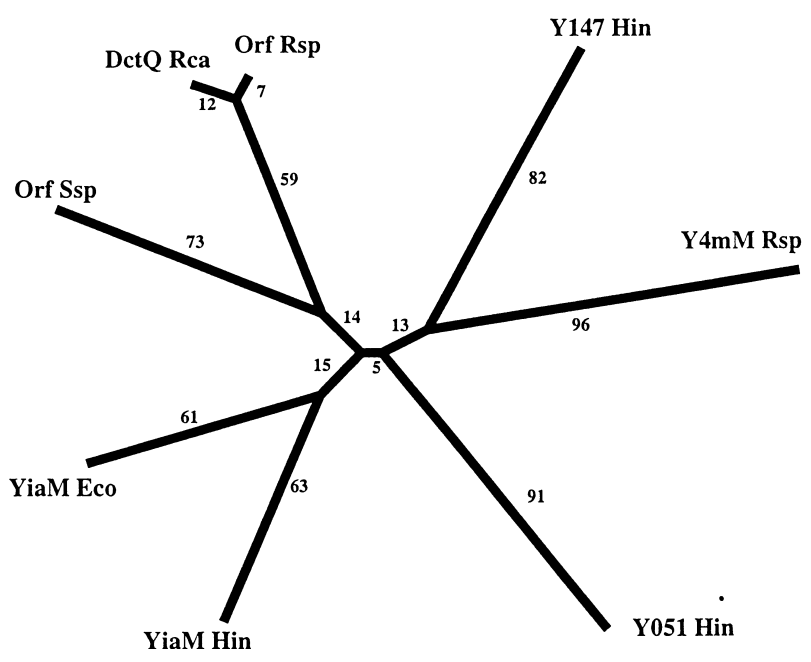

Fig. 3. Mean hydropathy plot (a), mean similarity plot (b) and phylogenetic tree (c) for the DctQ family. The black bar in (a) indicates the portion of the multiple alignment that is displayed on our Phylo web site. The abbreviations used in (c) are explained in Table 2. All three figures were derived from the multiple alignment generated with the TREE program as outlined in the legend to Fig. 2.

paralogues of Haemophilus influenzae display pronounced sequence divergence, but the putative YiaM orthologues of Escherichia coli and Haemophilus influenzae form a distinct cluster.

The most conserved portion of the complete multiple alignment is a gap-free 35 residue segment which shows three fully conserved amino acyl residues and several positions with only conservative substitutions (see our Phylo web site). The following signature sequence for the DctQ family was derived from this portion of the multiple alignment :

$$
\begin{aligned}
& \text { [LIVC]-F-x-[WLY]-[LIVMF]-x(2)-[LIVFG]-G-[AI]- } \\
& \text { [LIVAS]-[LIVY]-x(6)-H-[LIVM]-x-[LIV] }
\end{aligned}
$$

It proved to be specific to proteins of the DctQ family.

\section{The DctM family}

Table 3 lists proteins of the DctM family, eleven of which (those above the dashed line), all from Gramnegative bacteria, were included in the reported analyses. With the exceptions of DctM homologues from Rhodobacter sphaeroides, Rhodobacter capsulatus and Salmonella typhimurium, the protein sequences were obtained from completely sequenced genomes. The sizes of bacterial DctM family members were found to range from 389 to 445 residues with the exceptions of DctM of Treponema pallidum (632 residues), Y147 of Haemophilus influenzae (633 residues) and the three paralogues of Archaeoglobus fulgidus (643, 679 and 684 residues). These proteins have sizes equivalent to the approximate sum of DctQ and DctM, and in the case of the Haemophilus influenzae protein, the fusion of the DctM and DctQ homologues could be demonstrated. All of these larger homologues exhibit the same apparent topology with 16 putative TMSs. We therefore suggest that this type of fusion also occurred in the T. pallidum and Archaeoglobus fulgidus homologues but that extensive sequence divergence precluded recognition of the DctQ moiety.

Fig. 4 presents mean hydropathy (a) and mean similarity (b) plots for the 11 analysed members of the DctM family. The mean hydropathy plot reveals nine regions of hydrophobicity which span 20 residues or more. Three of these regions (residue positions 110-150, 250-300 and 350-400) probably encompass two TMSs each. Thus, the plot is consistent with the presence of 12 TMSs. The mean similarity plot reveals that almost without exception, each peak of high similarity aligns with a corresponding peak of hydrophobicity. Most of these hydrophobic peaks are about $80 \%$ similar.

Fig. 4(c) presents the DctM family phylogenetic tree. As observed for the DctP and DctQ family trees, DctM orthologues of Rhodobacter, DctM Rca and Orf Rsp form a tight cluster, although the DctM paralogues of Haemophilus influenzae display pronounced divergence. The YiaN orthologues of Escherichia coli and Haemophilus influenzae cluster together as do the DctP-like YiaO homologues and the DctQ-like YiaM homologues.

A portion of the complete multiple alignment upon which the plots and tree shown in Fig. 4 were based is presented on our Phylo web site. This gap-free alignment shows 3 fully conserved amino acyl residues in 34 
Table 3. Members of the DctM family

\begin{tabular}{|c|c|c|c|c|}
\hline Abbreviation & Name or description in database & Organism & $\begin{array}{c}\text { Size } \\
\text { (no. of residues) }\end{array}$ & $\begin{array}{l}\text { Database and } \\
\text { accession no. }\end{array}$ \\
\hline DctM Rca & $\begin{array}{l}\text { Large integral membrane transport } \\
\text { protein }\end{array}$ & Rhodobacter capsulatus & 440 & gbX63974 \\
\hline Orf Rsp & Similar to DctM in Rca & Rhodobacter sphaeroides & 443 & gbAF005842 \\
\hline Y147 Hin & Hypothetical protein HI0147 & Haemophilus influenzae & 633 & spP44543 \\
\hline Y050 Hin & Hypothetical protein HI0050 & Haemophilus influenzae & 401 & spP44483 \\
\hline YiaN Hin & Hypothetical protein HI1029 & Haemophilus influenzae & 425 & spP44993 \\
\hline YiaN Eco & $\begin{array}{l}\text { Hypothetical } 45.5 \mathrm{kDa} \text { protein in } \\
\text { avt } A \text {-selB intergenic region }\end{array}$ & Escherichia coli & 424 & spP37675 \\
\hline Y4mL Rsp & Hypothetical $44.6 \mathrm{kDa}$ protein $\mathrm{Y} 4 \mathrm{ML}$ & $\begin{array}{l}\text { Rhizobium sp. strain } \\
\text { NGR234 }\end{array}$ & 419 & spP55571 \\
\hline Orf Ssp & Hypothetical protein (Orf-ID sll1103) & $\begin{array}{l}\text { Synechocystis sp. strain } \\
\text { PCC } 6803\end{array}$ & 445 & gbD90913 \\
\hline OrfC Bpe & OrfC gene product & Bordetella pertussis & 389 & gbX64876 \\
\hline YgiK Sty & $\begin{array}{l}\text { Hypothetical } 46 \cdot 1 \mathrm{kDa} \text { protein in } p l s C \\
3^{\prime} \text { region }\end{array}$ & Salmonella typhimurium & 435 & $\mathrm{spP} 40800$ \\
\hline DctM Tpa & $\begin{array}{l}\text { Putative dicarboxylate transporter } \\
\text { (TP0958) }\end{array}$ & Treponema pallidum & 632 & gbAE001264 \\
\hline DctM Ral & Hypothetical protein, similar to YiaN & Ralstonia sp. strain TFD41 & 389 & gbAF045553 \\
\hline $\operatorname{DctM}_{1}$ Ape & Hypothetical protein, similar to YiaN & Aeropyrum pernix & 731 & gbAP000063 \\
\hline $\operatorname{DctM}_{2}$ Ape & Hypothetical protein, similar to YiaN & Aeropyrum pernix & 560 & gbAP000063 \\
\hline DctM Tma & Hypothetical protein, similar to YiaN & Thermotoga maritima & 427 & gbAE001714 \\
\hline $\mathrm{DctM}_{1} \mathrm{Pae}$ & Hypothetical protein & Pseudomonas aeruginosa & 427 & Not available* \\
\hline $\operatorname{DctM}_{2}$ Pae & Hypothetical protein & Pseudomonas aeruginosa & 427 & Not available* \\
\hline $\operatorname{DctM}_{3}^{2} \mathrm{Pae}$ & Hypothetical protein & Pseudomonas aeruginosa & 426 & Not available* \\
\hline $\operatorname{DctM}_{1}$ Afu & Hypothetical protein (AF0636) & Archaeoglobus fulgidus & 679 & gbAE001060 \\
\hline $\operatorname{DctM}_{2}$ Afu & Hypothetical protein (AF0466) & Archaeoglobus fulgidus & 684 & gbAE001072 \\
\hline $\operatorname{DctM}_{3}^{2} \mathrm{Afu}$ & Hypothetical protein (AF0989) & Archaeoglobus fulgidus & 643 & gbAE001036 \\
\hline
\end{tabular}

* Kindly provided by PathoGenesis Inc. (Seattle, USA) prior to publication.

residue positions with several positions exhibiting only conservative substitutions. The signature sequence for the DctM family is :

[LIVM]-[LIVMT]-A-[LIV]-P-[FL]-[FY]-[LIVMA]-x(2)$[G S]-x(2)-[L M]-x(2)-[G S T]-x(2)-[G A S T]-x(2)-[L I V M]$

\section{Additional members of the TRAP-T families in bacteria and archaea}

After completion of the sequence analyses reported, new sequences that proved to be homologous to the protein constituents of the three TRAP-T families were deposited in the databases. Some of these proteins are tabulated in Tables 1-3 below the dashed lines. Bacterial homologues identified include a complete DctPQM system from Ralstonia sp. strain TFD41 (Nakatsu et al., 1998), three complete paralogous DctPQM systems from Pseudomonas aeruginosa and one additional DctP paralogue from Pseudomonas aeruginosa. The comparison scores obtained with TRAP-T constituents of Rhodobacter capsulatus establish or strongly suggest homology (Table 4). The high comparison scores of the Pseudomonas aeruginosa proteins with those of Rhodo- bacter capsulatus suggest that they may also be dicarboxylate transporters (see Table 4). Hydropathy plots of the constituents of the complete systems from Ralstonia sp. strain TFD41 and Pseudomonas aeruginosa revealed that these proteins are similar in apparent topology to those described above.

By screening the incompletely sequenced genomes deposited in the NCBI databases, we identified homologues of complete TRAP-T systems in a number of additional bacteria. Thus, in the following organisms, DctM, DctP and DctQ homologues were detected with BLAST probability scores smaller than: $\mathrm{e}^{-25}$ for DctM, $\mathrm{e}^{-20}$ for DctP and 0.07 for DctQ when the Rhodobacter capsulatus proteins were used as the query sequences. Complete systems identified (with decreasing scores for DctM homologues in the order presented) were from the following bacteria: Vibrio cholerae, Shewanella putrefaciens, Bordetella pertussis, Enterococcus faecalis, Actinobacillus actinomycetemcomitans and Caulobacter crescentus. Many additional bacteria exhibit one or two homologues of the TRAP-T system, for example Thiosphaera pantotropha (now Paracoccus pantotrophus) (DctM) (Berks et al., 1995), and Thermotoga 

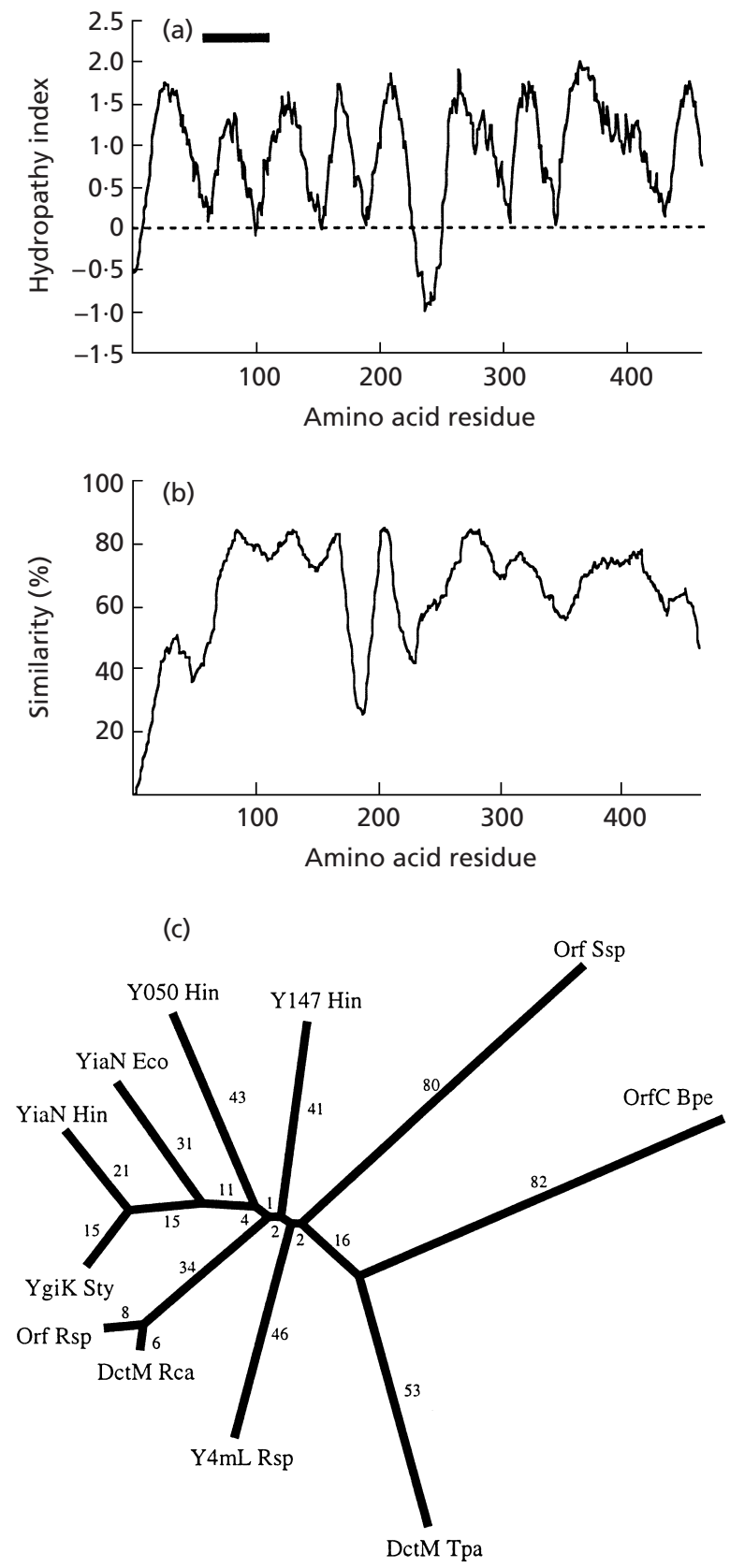

Fig. 4. Mean hydropathy plot (a), mean similarity plot (b) and phylogenetic tree (c) for the DctM family. The black bar in (a) indicates the portion of the multiple alignment that is displayed on our Phylo web site. The abbreviations used in (c) are explained in Table 3. All three figures were derived from the multiple alignment generated with the TREE program as outlined in the legend to Fig. 2.

maritima (DctPM). The fact that Enterococcus faecalis, a Gram-positive bacterium, exhibits all three Dct homologues allows us to conclude that TRAP-T systems are probably found in all major bacterial subdivisions.

Three DctM paralogues are encoded within the completely sequenced genome of the hyperthermophilic, sulfate-reducing archaeon Archaeoglobus fulgidus
(Klenk et al., 1997) and two more are found in a second archaeon, Aeropyrum pernix (Table 3). The Archaeoglobus fulgidus proteins proved to be more similar to the Ralstonia DctM protein than to the other bacterial homologues listed in Table 3. The comparison scores of these proteins with the Ralstonia DctM protein are presented in Table 4. Because these three proteins exhibit comparison scores with each other in excess of $20 \mathrm{sD}$, and two of them give comparison scores with the Ralstonia protein of 10 SD or greater, they can all be considered to be homologues. Fig. 5 shows a portion of the complete multiple alignment of the three Archaeoglobus fulgidus paralogues together with three selected bacterial members of the DctM family. Six positions are fully conserved, and only conservative substitutions are observed at many other positions. Consequently, there is little question that these proteins are homologous.

A mean hydropathy plot of the three Archaeoglobus fulgidus proteins is shown in Fig. 6(a). Sixteen putative TMSs are predicted, the same number that is observed for the bacterial DctQ plus DctM homologues (Figs 3a and 4a). PSI-BLAST searches revealed that all three Archaeoglobus fulgidus proteins exhibit an N-terminal region of 120-140 residues that is absent in all but one of the bacterial DctM protein homologues. The one exception is the Y147 protein of Haemophilus influenzae, which exhibits a fused DctQ-DctM structure with 16 putative TMSs. Attempts to establish significant sequence or motif similarity between the N-terminal sequences of the Archaeoglobus fulgidus proteins and the DctQ family homologues from bacteria were not successful. However, four observations suggested to us that they are equivalent: (1) they exhibit similar sizes; (2) they show similar topologies; (3) they show the same domain association as is present in the Y147 protein of Haemophilus influenzae; and (4) the bacterial DctQ homologues are far more divergent than the bacterial DctM homologues (see next section and Figs $3 \mathrm{~b}$ and $4 \mathrm{~b}$ ). We therefore suggest that all three Archaeoglobus fulgidus homologues include N-terminal DctQ equivalents even though we cannot prove this postulate.

Adjacent to each of the genes encoding one of the three paralogous $\operatorname{Dct}(\mathrm{Q}) \mathrm{M}$ proteins in Archaeoglobus fulgidus, we found a gene encoding a DctP-like protein (see Table 1). All of the latter three genes were homologous to each other. While homology between $\mathrm{Orf}_{1}$ and $\mathrm{Orf}_{2}$ was pronounced (percentage identity of $38 \%$ ), $\mathrm{Orf}_{3}$ proved to be more distant from the two other paralogues (percentage identity of $21.5 \%$ and $23.4 \%$, respectively). This is in agreement with the observation that DctM $_{3}$ is also more distant from DctM and $\operatorname{DctM}_{2}$. All three putative DctP paralogues exhibit a hydrophilic nature except for hydrophobic N-termini as expected for extracytoplasmic solute-binding receptors (Fig. 6b). PSI-BLAST searches revealed motif similarity of these three archaeal proteins to the periplasmic glutamine-binding protein of Escherichia coli. Thus, three complete TRAP-T systems appear to be present in Archaeoglobus fulgidus. 
Table 4. Comparison scores of newly identified TRAP-T constituents

\begin{tabular}{|c|c|c|c|}
\hline & & \multicolumn{2}{|c|}{$\begin{array}{l}\text { Comparison scores (SD) with } \\
\text { Rhodobacter capsulatus }\end{array}$} \\
\hline & DctM & DctP & DctQ \\
\hline DctMPQ of Ralstonia sp. strain TFD41 & 13 & 12 & 4 \\
\hline $\operatorname{DctM}_{1} \mathrm{P}_{1} \mathrm{Q}_{1}$ of Pseudomonas aeruginosa & 62 & 45 & 14 \\
\hline Dct $\mathrm{M}_{2} \mathrm{P}_{2} \mathrm{Q}_{2}$ of Pseudomonas aeruginosa & 57 & 51 & 11 \\
\hline $\operatorname{DctM}_{3} \mathrm{P}_{3} \mathrm{Q}_{3}$ of Pseudomonas aeruginosa & 45 & 17 & 1 \\
\hline \multirow[t]{3}{*}{ DctP $_{4}$ of Pseudomonas aeruginosa } & - & 39 & - \\
\hline & \multicolumn{3}{|c|}{ Comparison score (SD) with } \\
\hline & $\begin{array}{l}\text { DctM of Ralstonia sp. } \\
\text { strain TFD41 }\end{array}$ & \multicolumn{2}{|c|}{$\begin{array}{c}\text { DctM }_{1} \text { of } \\
\text { Archaeoglobus fulgidus }\end{array}$} \\
\hline DctM $_{1}$ of Archaeoglobus fulgidus & 11 & \multicolumn{2}{|c|}{-} \\
\hline DctM $_{2}$ of Archaeoglobus fulgidus & 10 & \multicolumn{2}{|c|}{42} \\
\hline DctM $_{3}$ of Archaeoglobus fulgidus & $7 \cdot 5$ & \multicolumn{2}{|c|}{24} \\
\hline
\end{tabular}

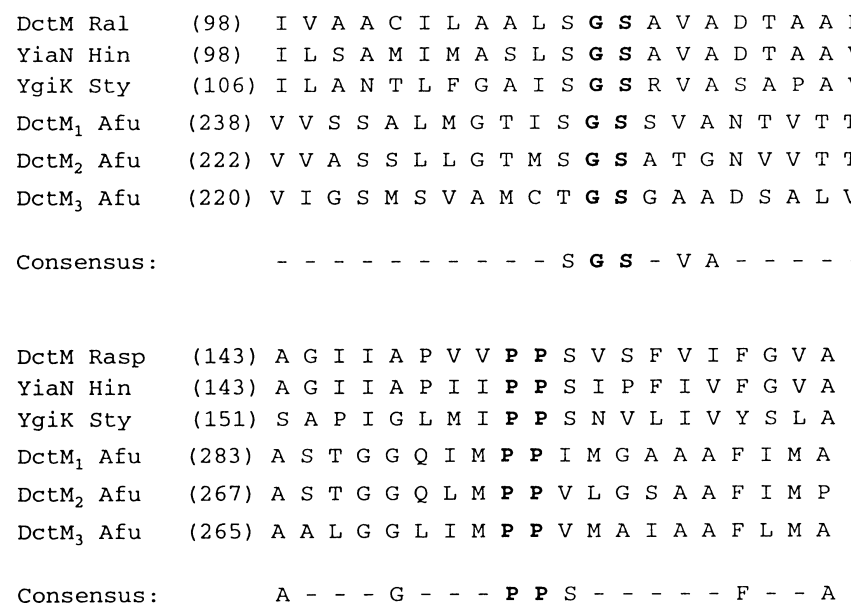

Fig. 5. A portion of a multiple alignment for representative bacterial and archaeal members of the DctM family. Abbreviations are explained in Table 3.

Immediately adjacent to the genes encoding the putative DctPQM $\mathrm{D}_{2}$ transporter of Archaeoglobus fulgidus, we noted the presence of a gene cluster (korBADG) encoding the four subunits of the 2oxoglutarate: ferridoxin 2-oxidoreductase (Klenk et al., 1997). The clustering of these genes suggests a common function. The proposed function of $\operatorname{DctPQM}_{2}$ is therefore that of a 2-oxoglutarate uptake system.

\section{Relative degrees of sequence divergence among the three TRAP-T family constituents}

We noted that DctM homologues seem to exhibit greater percentage identity values with each other than do DctQ or DctP homologues. We therefore analysed all pairs of homologues of the complete TRAP-T systems represented in the trees shown in Figs 2(c), 3(c) and 4(c). Percentage identity values were calculated for all pairs of homologues and these values were averaged. The mean percentage identity values for all pairs of DctM, DctP and DctQ homologues were $34.5 \%, 29.6 \%$ and $20.6 \%$, respectively. These results provide quantitative estimates of the relative rates of sequence divergence. They show that DctQ homologues have diverged in sequence more rapidly than DctP homologues, and that DctP homologues have diverged more rapidly than DctM homologues. This fact may well account for our inability to detect DctQ or DctP homologues for some of the DctM homologues in organisms with completely (and incompletely) sequenced genomes (see Discussion). 


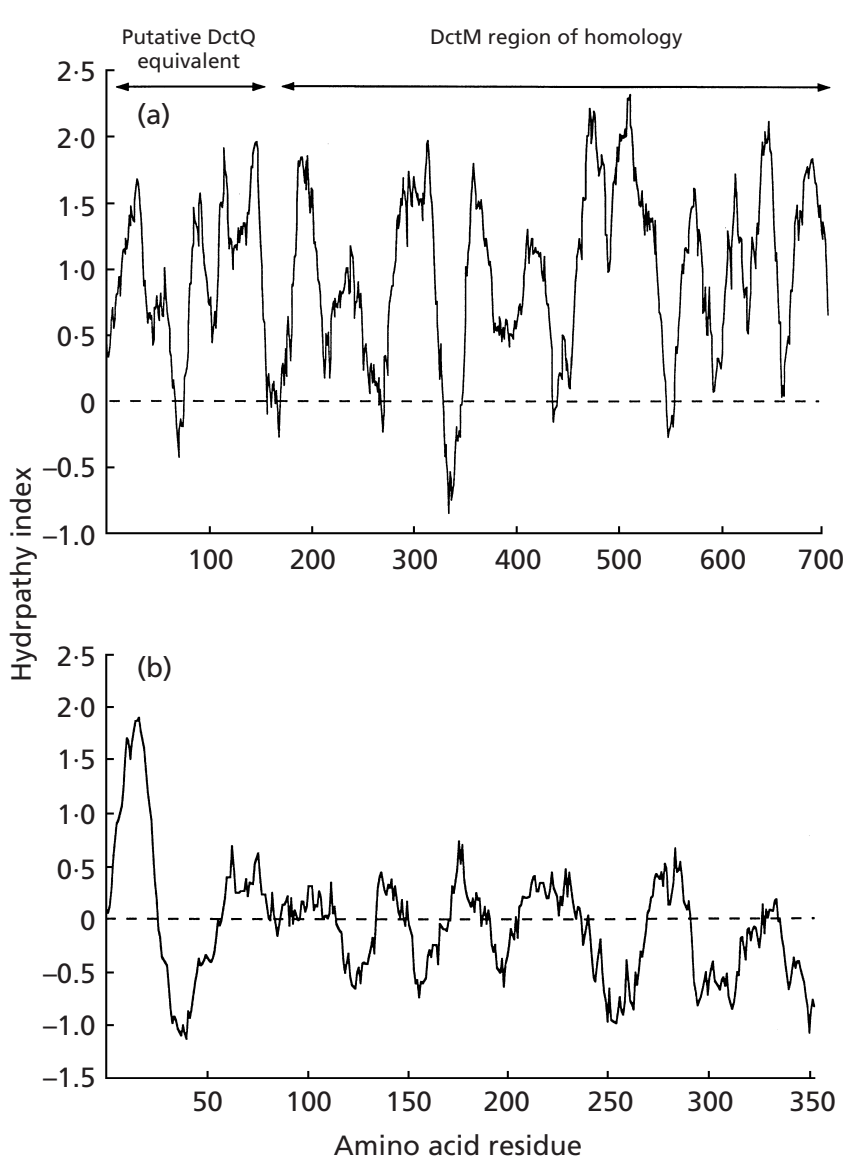

Fig. 6. Mean hydropathy plots of the three $\operatorname{Dct}(\mathrm{Q}) \mathrm{M}$ (a) and DctP (b) paralogues from Archaeoglobus fulgidus. The $\mathrm{N}$ terminal portion of 4 TMSs in the $\operatorname{Dct}(\mathrm{Q}) \mathrm{M}$ proteins comprises the putative DctQ equivalent; the C-terminal portion of 12 TMSs represents the region homologous to bacterial members of the DctM family.

\section{Preliminary evidence that DctM is a member of a large superfamily of ion transporters}

We have previously described and classified over 200 families of transporters (see our web site: http://wwwbiology.ucsd.edu/ $\sim$ msaier/transport.html). Use of the PSI-BLAST program (Altschul et al., 1997) suggested that eleven of these previously identified families exhibit common matrices of sequence motifs. These families are listed by name in Table 5 together with their abbreviations, TC numbers and a well-characterized protein example. Database accession numbers are provided for these proteins, allowing easy access to their sequences. All eleven of the families identified function in the transport of organic or inorganic ions. We therefore have designated this putative superfamily the ion transporter (IT) superfamily.

Using the MEME and MAST programs (Bailey \& Gribskov, 1998), we have examined these families for common motifs. The results are summarized in Table 6. The Ars family proved to exhibit recognizable motif similarity with four of these families as summarized in the top panel of Table 6. Among these are the GntP and LctP families, which exhibit extensive motif similarities as revealed in the lower panel of Table 6. The TRAP-T DctM family exhibits an N-terminal motif in common with the DcuC family, but this family is not among those that show motif commonality with the Ars family as revealed by MEME and MAST. The basis for the PSI-BLAST results suggesting common ancestry of the eleven families of the putative IT superfamily is therefore only partially revealed by the output of the MEME and MAST programs.

\section{DISCUSSION}

Only a single member of the TRAP-T family of transporters has been both molecularly and functionally characterized (Forward et al., 1997). This system is the three component DctPQM system where DctM and DctQ are integral membrane constituents with 12 and 4 putative TMSs, respectively, and DctP is a periplasmic solute-binding receptor. These proteins have previously been shown to function together, and all of them are required for detectable transport activity (Forward et al., 1997). Our analyses have revealed the presence of complete TRAP-T systems in a large variety of bacteria and archaea, but not in eukaryotes. In Bacillus subtilis, a single DctP homologue was identified, but no DctM or DctQ homologue could be found. We therefore suggest that in Bacillus subtilis, the DctP homologue functions by a mechanism that differs from that in other bacteria. Adjacent to the Bacillus subtilis $y d b E$ gene encoding the DctP homologue is the $y d b F$ gene encoding a sensor kinase, the $y d b G$ gene encoding a response regulator and the $y d b H$ gene encoding a DcuA (dicarboxylate transporter) homologue of the DAACS family (TC no. 2.23). In Agrobacterium tumefaciens, a periplasmic binding protein, ChvE, interacts with a sensor kinase to effect induction of the vir operon (Cangelosi et al., 1990; Winans, 1991). In this case, the binding protein also functions as a constituent of an ABC-type transporter (Kemner et al., 1997) and as a chemoreceptor (Cangelosi et al., 1990). We would like to suggest that the YdbE extracytoplasmic binding protein serves as a receptor for one or more dicarboxylates, and interacts with the YdbF sensor kinase to activate it for phosphorylating the YdbG response regulator that controls transcription of the $y d b H$ gene encoding a dicarboxylate transporter. Indeed, hydropathy analyses revealed that $\mathrm{YdbF}$ exhibits two putative TMSs centred at residues 20 and 180, suggesting a topology similar to that of VirA of Agrobacterium tumefaciens. The intervening region (residues 30-170) presumably binds YdbE. This suggestion is further substantiated by the observation that in Rhizobium leguminosarum, the $\operatorname{dct} A$ gene is controlled transcriptionally by a sensor kinase-response regulator system that renders induction responsive to extracellular dicarboxylates (Huala et al., 1992). We propose that a similar induction mechanism operates in Bacillus subtilis.

The genome of the archaeon Archaeoglobus fulgidus was shown to encode three DctM homologues and all of these possess $\mathrm{N}$-terminal regions that are homologous 
Table 5. Families believed to constitute the IT superfamily

As suggested by PSI-BLAST studies.

\begin{tabular}{|c|c|c|c|}
\hline Transporter family & Abbreviation & TC no.* & Example $\dagger$ \\
\hline Gluconate: $\mathrm{H}^{+}$symporter family & GntP & 2.8 & GntP of Bacillus subtilis (spP12012) \\
\hline $\begin{array}{l}\text { Citrate- } \mathrm{Mg}^{2+}: \mathrm{H}^{+}(\mathrm{CitM}) \text {-citrate }: \mathrm{H}^{+}(\mathrm{CitH}) \\
\text { symporter family }\end{array}$ & CitMHS & 2.11 & CitM of Bacillus subtilis (spP55069) \\
\hline $\mathrm{C}_{4}$-dicarboxylate uptake family & Dcu & 2.13 & DcuA of Escherichia coli (spP04539) \\
\hline Lactate permease family & LctP & 2.14 & LctP of Escherichia coli (spP33231) \\
\hline $\mathrm{NhaB} \mathrm{Na}^{+}: \mathrm{H}^{+}$antiporter family & NhaB & 2.34 & NhaB of Escherichia coli (spP27377) \\
\hline $\mathrm{NhaC} \mathrm{Na}^{+}: \mathrm{H}^{+}$antiporter family & NhaC & 2.35 & NhaC of Bacillus firmus (gbU61539) \\
\hline $\mathrm{NhaD} \mathrm{Na}^{+}: \mathrm{H}^{+}$antiporter family & NhaD & 2.62 & $\begin{array}{l}\text { NhaD of Vibrio parahaemolyticus } \\
\text { (gbAB006008) }\end{array}$ \\
\hline Divalent anion: $\mathrm{Na}^{+}$symporter family & DASS & 2.47 & SodiT1 of Spinacia oleracea (gbU13238) \\
\hline $\begin{array}{l}\text { Tripartite ATP-independent periplasmic } \\
\text { transporter family }\end{array}$ & TRAP-T & 2.56 & DctM of Rhodobacter capsulatus (gbX63974) \\
\hline $\mathrm{C}_{4}$-dicarboxylate uptake $\mathrm{C}$ family & DcuC & 2.61 & DcuC of Escherichia coli (spQ47134) \\
\hline Arsenical efflux family & Ars & 3.4 & $\begin{array}{l}\text { ArsA-ArsB of Escherichia coli (ArsA: } \\
\text { spP08690; ArsB: spP37310) }\end{array}$ \\
\hline
\end{tabular}

*According to the TC system (see our web site and Saier, 1998).

† Accession numbers given in parentheses.

with each other. These N-terminal regions exhibit sizes and topological features that resemble the bacterial DctQ homologues. In Haemophilus influenzae, one of the three TRAP-T systems identified exhibits a fused DctQM protein of 16 TMSs. Since the Archaeoglobus fulgidus paralogues also exhibit 16 putative TMSs, it is reasonable to propose that the Archaeoglobus fulgidus homologues represent the equivalent of both DctQ and DctM of Rhodobacter capsulatus. This suggestion is in agreement with our observation that the bacterial DctQ homologues have diverged much more rapidly than have the DctM homologues. Adjacent to each of the Dct $(\mathrm{Q}) \mathrm{M}$ homologues of Archaeoglobus fulgidus is a gene encoding a putative extracytoplasmic solute-binding receptor with significant sequence and motif similarity to the well-characterized glutamine- and glutamate-binding proteins of ABC-type transporters in Escherichia coli. These three archaeal proteins exhibit a single $\mathrm{N}$ terminal hydrophobic peak followed by regions of relative hydrophilicity as expected for an extracytoplasmic solute-binding protein. It seems likely that these three Archaeoglobus fulgidus proteins function as the solute-binding receptors for the $\operatorname{Dct}(\mathrm{Q}) \mathrm{M}$ homologues of this organism. This suggestion is substantiated by the observation that the genes encoding the four subunits of 2-oxoglutarate: ferridoxin 2-oxidoreductase map immediately adjacent to the $\operatorname{dctPQM} M_{2}$ genes of Archaeoglobus fulgidus.

The great degree of sequence divergence between the constituents of the bacterial and archaeal TRAP-T systems suggests that they are related by vertical descent, and that horizontal transmission of genetic material between these two domains of living organisms does not account for their occurrences. This observation leads to the suggestion that the TRAP-T family is very old, dating back to before the split between bacteria and archaea.

Encoded within the fully sequenced genome of Treponema pallidum, a DctM homologue was identified. This protein exhibits the same size and apparent topology as the DctQM protein of Haemophilus influenzae with the non-homologous putative DctQ moiety at the N-terminus. Moreover, adjacent to the gene encoding this protein were two genes encoding proteins of about 330 amino acyl residues which exhibited $\mathrm{N}$-terminal peaks of hydrophobicity. Either of these proteins could be the solute-binding receptor for the $\operatorname{Dct}(\mathrm{Q}) \mathrm{M}$ homologue of $T$. pallidum. Thus $T$. pallidum may possess a complete DctPQM transporter as is apparently true for many other prokaryotes.

DctP, DctQ and DetM occur in many bacteria as distinct polypeptide chains encoded by three contiguous genes, usually in operons with the gene order dctPQM. However, we found two types of protein (or domain) fusions. One is DctPQ (Y4 mM from Rhizobium sp. strain NGR243) and the other is DctQM (Y147 from Haemophilus influenzae and several other organisms). None of the other possible domain orders (i.e. DctQP, DctMQ, DctPM and DctMP) were found. This observation leads to the prediction that P interacts with $\mathrm{Q}$, and $\mathrm{Q}$ with $\mathrm{M}$ in all DctPQM homologues. DctQ may serve as a structural anchor for DctP, allowing association of $\mathrm{P}$ with $\mathrm{M}$, a suggestion that is consistent with the relative rates of divergence of these three TRAP-T protein constituents. It is also interesting to note that no DctPQM fusions have been detected, and that this fact correlates with the fact that in ABC uptake permeases, the extracytoplasmic receptors are seldom 
Table 6. Motifs common among members of the proposed IT superfamily as identified by MEME and MAST analyses

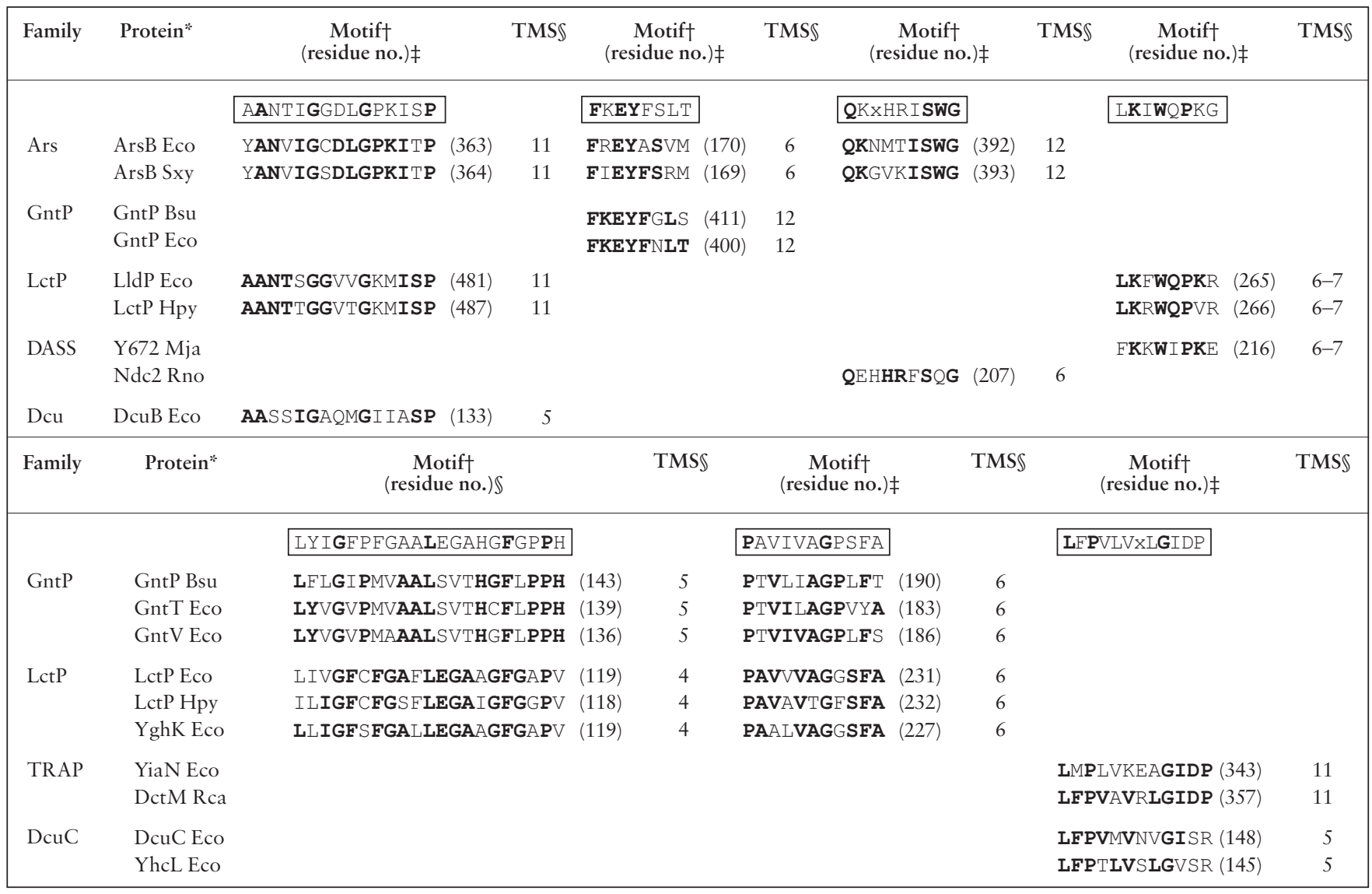

*ArsB Eco, ArsB of Escherichia coli (accession no. spP37310); ArsB Sxy, ArsB of Staphylococcus xylosus (spQ01255); GntP Bsu, GntP of Bacillus subtilis (spP12012); Gnt Eco, Gnt of Escherichia coli (spP39835); GntV Eco, GntV of Escherichia coli (spP39344); LctP of Escherichia coli (spP33231); LldP Eco, LldP of Escherichia coli (gbACC76011); LctP Hpy, LctP of Helicobacter pylori (gbAE000535); YghK Eco, YghK of Escherichia coli (spQ46839); Y672 MJA, Y672 of Methanococcus jannaschii (spQ58086); Ndc2 Rno, Ndc2 of Rattus norvegicus (spP70545); DcuB Eco, DcuB of Escherichia coli (spP14409); YiaN Eco, YiaN of Escherichia coli (spP37675); DctM Rca, DctM of Rhodobacter capsulatus (gbX63974); DcuC Eco, DcuC of Escherichia coli (spQ47134); YhcL Eco, YhcL of Escherichia coli (spP45428).

† Motifs (boxed) were determined using the MEME program (Grundy et al., 1997). Residues in bold print in the boxed motifs were conserved in all proteins analysed. Residues in bold print in non-boxed motifs are common to the members of that family.

$\ddagger$ Position of the identified motif in a given protein.

$\$$ Number of the TMS of a given protein in which the identified motif resides.

fused to the integral membrane translocator protein (Obis et al., 1999). Possibly this last fact points to additional non-transport-related functions (e.g. chemoreception, regulation) for these proteins.

We have obtained preliminary evidence that DctM may be a member of a large superfamily of ion transporters which we have tentatively designated the ion transporter (IT) superfamily. Among the members of this supe-rfamily are many well-documented secondary transporters that function without the participation of a extracytoplasmic receptor or an integral membrane auxiliary protein. This fact strengthens our conviction that in Rhodobacter capsulatus, DctM alone provides the pathway of solute transport, and that DctQ and DctP function in accessory capacities. In confirmation of this suggestion we note that both Pseudomonas aeruginosa and Synechocystis sp. strain PCC6803 apparently have a surplus of genes encoding DctP homologues with no corresponding $d c t Q$ - or $d c t M$-like genes mapping nearby. Either these proteins serve as auxiliary binding receptors for the recognized TRAP-T family systems in these organisms, or they serve entirely different functions as we have proposed for Bacillus subtilis.

Another member of the putative IT superfamily (see Tables 5 and 6) is the ArsB protein of Escherichia coli, a constituent of the Ars family (TC no. 3.4). In this organism, ArsB can function together with ArsA to form an ATP-dependent anion translocator. However, in the absence of ArsA, ArsB transports arsenite and antimonite in a p.m.f.-driven process (Kuroda et al., 1997; Silver et al., 1993). The auxiliary protein, ArsA, has 
evidently been superimposed on the integral membrane secondary transporter ArsB, allowing the use of ATP to energize transport. It seems that members of the IT superfamily exhibit the unusual characteristic of allowing superimposition of additional protein constituents on the basic transport process that modify transport characteristics by allowing high-affinity solute reception (e.g. using DctP), by altering the energy coupling mechanism (e.g. using ArsA) or by providing an unknown function (e.g. DctQ). The molecular basis for this unusual characteristic remains to be elucidated.

DctP is a periplasmic solute-binding protein with many characteristics that typify the extracytoplasmic receptors of ABC transporters (Tam \& Saier, 1993). For example, DctP is the same size as many of the latter proteins and it confers high-affinity substrate binding and recognition to its transporter (Walmsley et al., 1992). We have noted that DctP exhibits regions of limited sequence similarity to binding receptors of $A B C$ systems including the citrate-binding protein of Salmonella typhimurium (Tam \& Saier, 1993). We therefore propose that although sequence divergence is very considerable, the DctP proteins, as well as the putative Archaeoglobus fulgidus solute-binding receptors, represent authentic constituents of the solutebinding receptor superfamily that includes all extracytoplasmic receptors that feed into ABC transporters (Kuan et al., 1995; Quiocho \& Ledvina, 1996; Tam \& Saier, 1993). In this connection it is interesting to note that neither ABC uptake systems nor TRAP-T uptake systems, both of which are dependent on extracytoplasmic receptors, are found in eukaryotes. Either binding-protein-dependent transport arose after prokaryotes and eukaryotes diverged from each other during the 'great split', or such a transport mode is inconsistent with eukaryotic life-styles. In either case, it seems that horizontal transmission of genetic material encoding transport proteins between prokaryotes and eukaryotes has been exceptionally rare (Saier, 1998, 1999). This postulate also leads to the possibility that $\mathrm{ABC}$ uptake systems arose from ABC-type efflux systems that function independently of binding receptors and are found ubiquitously throughout the three domains of life (Saurin et al., 1999).

Several members of the IT superfamily arose by an intragenic duplication event that gave rise to proteins of 12 TMSs from primordial systems that presumably exhibited 6 TMSs (Saier \& Tseng, 1999). Most dramatic is the ArsB protein where the degree of sequence similarity between the halves is sufficient to easily establish homology (Saier \& Tseng, 1999; unpublished observation). Attempts to document an internal duplication in DctM led to recognition of sequence similarity between its two halves, but this similarity was insufficient to establish homology (unpublished observation). We suggest either that the two halves of DctM diverged in sequence more rapidly than did those in ArsB or that the duplication event leading to the fulllength DctM homologues occurred earlier than the one that gave rise to ArsB homologues. The latter interpret- ation is in agreement with conclusions reached from studies of another large superfamily, the RND superfamily (Tseng et al., 1999). Regardless of this possibility, however, we predict that all IT superfamily transporters will prove to have arisen by intragenic duplication.

In spite of the fact that an 'orphan' DctP homologue appears to exist in Bacillus subtilis, an organism with a fully sequenced genome, and that a few ' extra' receptors may be present in a few other bacteria, our phylogenetic analyses suggest that in bacteria, and probably in archaea as well, the three constituents of complete TRAP-T systems evolved in parallel from a single primordial three-component (or three-domain) transport system. If this contention is correct, it would imply that intact TRAP-T systems did not arise recently by the superimposition of accessory proteins on the putative DctM transporter, but that these three proteins have functioned together for billions of years with minimal shuffling of constituents between systems. This conclusion is in agreement with the observation that such shuffling has seldom occurred during the evolution of the ubiquitous ABC superfamily (TC no. 3.1; Kuan et al., 1995), the bacterial phosphotransferase functional superfamily (TC no. 6.1-6.6; Postma et al., 1993) and the integral membrane constituents of F-type ATPases (TC no. 3.2; Blair et al., 1996). Moreover, the demonstrable sequence similarity between the putative DctP homologues in Archaeoglobus fulgidus and the glutamine/glutamate-binding proteins of bacteria leads further to the suggestion that all DctP homologues are part of the binding protein superfamily (Quiocho \& Ledvina, 1996). The general picture that seems to be emerging is that once a multicomponent transport system has appeared, it undergoes diversification following gene duplication and during speciation with minimal shuffling of constituents between functional units. Both ABC and TRAP-T uptake systems must have arisen during molecular antiquity but have retained their independent lineages. The molecular, physiological and regulatory constraints imposed upon transporters that prevent shuffling have yet to be elucidated.

\section{ACKNOWLEDGEMENTS}

We thank PathoGenesis Inc. (Seattle, USA) for allowing access to the Pseudomonas aeruginosa genome prior to publication. We thank Ian T. Paulsen, Tsai-Tien Tseng, Martin J. Hicks, Wilbert H. M. Heijne and Christel Krüger for expert assistance with some of the sequence analyses reported. Assistance with manuscript preparation was provided by Milda Simonaitis. This research was supported by USPHS grants 2RO1GM55434 from the National Institute of General Medical Sciences and 2R01 AI 14176 from the National Institute of Allergy and Infectious Diseases to M. H. Saier, Jr, and a grant from the UK Biotechnology and Biological Sciences Research Council to D. J. Kelly. R. Rabus was supported by a Feodor Lynen fellowship from the Alexander von Humboldt Society of Germany.

\section{REFERENCES}

Altschul, S. F., Gish, W., Miller, W., Myers, E. W. \& Lipman, D. J. (1990). Basic local alignment search tool. J Mol Biol 215, 403-410. 
Altschul, S. F., Madden, T. L., Schäffer, A. A., Zhang, J., Zhang, Z., Miller, W. \& Lipman, D. J. (1997). Gapped BLAST and PSI-BLAST : a new generation of protein database search programs. Nucleic Acids Res 25, 3389-3402.

Ames, G. F.-L. (1986). Bacterial periplasmic transport systems: structure, mechanism, and evolution. Annu Rev Biochem 55, 397-425.

Bailey, T. L. \& Gribskov, M. (1998). Combining evidence using pvalues: application to sequence homology searches. Bioinformatics 14, 48-54.

Bairoch, A., Bucher, P. \& Hofmann, K. (1997). The PROSITE database, its status in 1997. Nucleic Acids Res 25, 217-221.

Berks, B. C., Richardson, D. J., Reilly, A., Willis, A. C. \& Ferguson, S. J. (1995). The napEDABC gene cluster encoding the periplasmic nitrate reductase system of Thiosphaera pantotropha. Biochem J 309, 983-992.

Blair, A., Ngo, L., Park, J., Paulsen, I. T. \& Saier, M. H., Jr (1996). Phylogenetic analyses of the homologous transmembrane channel-forming proteins of the $\mathrm{F}_{0} \mathrm{~F}_{1}$-ATPases of bacteria, chloroplasts and mitochondria. Microbiology 142, 17-32.

Boos, W. \& Lucht, J. M. (1996). Periplasmic binding proteindependent $\mathrm{ABC}$ transporters. In Escherichia coli and Salmonella: Cellular and Molecular Biology, 2nd edn, pp. 1175-1209. Edited by F. C. Neidhardt and others. Washington, DC: American Society for Microbiology.

Cangelosi, G. A., Ankenbauer, R. G. \& Nester, E. W. (1990). Sugars induce the Agrobacterium virulence genes through a periplasmic binding protein and a transmembrane signal protein. Proc Natl Acad Sci USA 87, 6708-6712.

Dayhoff, M. O., Barker, W. C. \& Hunt, L. T. (1983). Establishing homologies in protein sequences. Methods Enzymol 91, 524-545.

Devereux, J., Haeberli, P. \& Smithies, O. (1984). A comprehensive set of sequence analysis programs for the VAX. Nucleic Acids Res 12, 387-395.

Felsenstein, J. (1985). Confidence limits on phylogenies: an approach using the bootstrap. Evolution 39, 783-791.

Feng, D.-F. \& Doolittle, R. F. (1990). Progressive alignment and phylogenetic tree construction of protein sequences. Methods Enzymol 183, 375-387.

Forward, J. A., Behrendt, M. C., Wyborn, N. R., Cross, R. \& Kelly, D. J. (1997). TRAP transporters: a new family of periplasmic solute transport systems encoded by the $\operatorname{dctPQM}$ genes of Rhodobacter capsulatus and by homologs in diverse Gramnegative bacteria. J Bacteriol 179, 5482-5493.

Grundy, W. N., Bailey, T. L., Elkan, C. P. \& Baker, M. E. (1997). Meta-meme: motif-based hidden Markov models of protein families. Comput Appl Biosci 13, 397-406.

Hamblin, M. J., Shaw, J. G., Curson, J. P. \& Kelly, D. J. (1990). Mutagenesis, cloning and complementation analysis of $\mathrm{C}_{4^{-}}$ dicarboxylate transport genes from Rhodobacter capsulatus. Mol Microbiol 4, 1567-1574.

Higgins, C. F. (1992). ABC transporters: from microorganisms to man. Annu Rev Cell Biol 8, 67-113.

Higgins, C. F., Hyde, S. C., Mimmack, M. M., Gileadi, U., Gill, D. R. \& Gallagher, M. P. (1990). Binding protein-dependent transport systems. J Bioenerg Biomembr 22, 571-592.

Huala, E., Stigter, J. \& Ausubel, F. M. (1992). The central domain of Rhizobium leguminosarum DctD functions independently to activate transcription. J Bacteriol 174, 1428-1431.

Hyde, S. C., Emsley, P., Hartshorn, M. J. \& 7 other authors (1990). Structural model of ATP-binding proteins associated with cystic fibrosis, multidrug resistance and bacterial transport. Nature 346, 362-365.

Jacobs, M. H. J., van der Heide, T., Driessen, A. J. M. \& Konings, W. N. (1996). Glutamate transport in Rhodobacter sphaeroides is mediated by a novel binding protein-dependent secondary transport system. Proc Natl Acad Sci USA 93, 12786-12790.

Kemner, J. M., Liang, X. \& Nester, E. W. (1997). The Agrobacterium tumefaciens virulence gene chvE is part of a putative ABC-type sugar transport operon. J Bacteriol 179, 2452-2458.

Klenk, H.-P., Clayton, R. A., Tomb, J.-F. \& 48 other authors (1997). The complete genome sequence of the hyperthermophilic, sulphate-reducing archaeon Archaeoglobus fulgidus. Nature 390, 364-370.

Kuan, G., Dassa, E., Saurin, W., Hofnung, M. \& Saier, M. H., Jr (1995). Phylogenetic analyses of the ATP-binding constituents of bacterial extracytoplasmic receptor-dependent ABC-type nutrient uptake permeases. Res Microbiol 146, 271-278.

Kuroda, M., Dey, S., Sanders, O. I. \& Rosen, B. P. (1997). Alternate energy coupling of ArsB, the membrane subunit of the Ars aniontranslocating ATPase. J Biol Chem 272, 326-331.

Kyte, J. \& Doolittle, R. F. (1982). A simple method for displaying the hydropathic character of a protein. J Mol Biol 157, 105-132.

Le, T., Tseng, T.-T. \& Saier, M. H., Jr (1999). Flexible programs for the prediction of average amphipathicity of multiply aligned homologous proteins: application to integral membrane transport proteins. Mol Membr Biol 16, 173-179.

Maloney, P. C. (1994). Bacterial transporters. Curr Opin Cell Biol 6, 571-582.

Maloney, P. C. \& Wilson, T. H. (1996). Ion-coupled transport and transporters. In Escherichia coli and Salmonella: Cellular and Molecular Biology, 2nd edn, pp. 1130-1148. Edited by F. C. Neidhardt and others. Washington, DC: American Society for Microbiology.

Nakatsu, C. H., Korona, R., Lenski, R. E., DeBruijn, F. J., Marsh, T. L. \& Forney, L. J. (1998). Parallel and divergent genotypic evolution in experimental populations of Ralstonia sp. J Bacteriol 180, $4325-4331$.

Nikaido, H. \& Saier, M. H., Jr (1992). Transport proteins in bacteria: common themes in their design. Science 258, 936-942.

Obis, D., Guillot, A., Gripon, J.-C., Renault, P., Bolotine, A. \& Mistou, M. Y. (1999). Genetic and biochemical characterization of a high-affinity betaine uptake system (BusA) in Lactococcus lactis reveals a new functional organization within bacterial $\mathrm{ABC}$ transporters. J Bacteriol (in press).

Pearson, W. R. \& Lipman, D. J. (1988). Improved tools for biological sequence comparison. Proc Natl Acad Sci USA 85, 2444-2448.

Postma, P. W., Lengeler, J. W. \& Jacobson, G. R. (1993). Phosphoenolpyruvate: carbohydrate phosphotransferase systems of bacteria. Microbiol Rev 57, 543-594.

Quiocho, F. A. \& Ledvina, P. S. (1996). Atomic structure and specificity of bacterial periplasmic receptors for active transport and chemotaxis : variation of common themes. Mol Microbiol 20, 17-25.

Saier, M. H., Jr (1994). Computer-aided analyses of transport protein sequences: gleaning evidence concerning function, structure, biogenesis, and evolution. Microbiol Rev 58, 71-93.

Saier, M. H., Jr (1998). Molecular phylogeny as a basis for the classification of transport proteins from Bacteria, Archaea and Eukarya. Adv Microb Physiol 40, 81-136.

Saier, M. H., Jr (1999). Eukaryotic transmembrane solute transport 
systems. In International Review of Cytology: a Survey of Cell Biology, pp. 61-136. Edited by K. W. Jeon. San Diego: Academic Press.

Saier, M. H., Jr \& Tseng, T.-T. (1999). Evolutionary origins of transmembrane transport systems. In Transport of Molecules Across Microbial Membranes, Society for General Microbiology Symposium 58, pp. 252-274. Cambridge: Cambridge University Press.

Saurin, W., Hofnung, M. \& Dassa, E. (1999). Getting in or out: early segregation between importers and exporters in the evolution of ATP-binding cassette (ABC) transporters. J Mol Evol 48, 22-41.

Shaw, J. G. \& Kelly, D. J. (1991). Binding protein dependent transport of $\mathrm{C}_{4}$-dicarboxylates in Rhodobacter capsulatus. Arch Microbiol 155, 466-472.

Shaw, J. G., Hamblin, M. J. \& Kelly, D. J. (1991). Purification, characterization and nucleotide sequence of the periplasmic $\mathrm{C}_{4}{ }^{-}$ dicarboxylate-binding protein (DctP) from Rhodobacter capsulatus. Mol Microbiol 5, 3055-3062.

Silver, S., Ji, G., Bröer, S., Dey, S., Du, D. \& Rosen, B. P. (1993). Orphan enzyme or patriarch of a new tribe: the arsenic resistance ATPase of bacterial plasmids. Mol Microbiol 8, 637-642.

Tam, R. \& Saier, M. H., Jr (1993). Structural, functional, and evolutionary relationships among extracellular solute-binding receptors of bacteria. Microbiol Rev 57, 320-346.

Thompson, J. D., Gibson, T. J., Plewniak, F., Jeanmougin, F. \& Higgins, D. G. (1997). The CLUSTAL $x$ windows interface: flexible strategies for multiple sequence alignment aided by quality analysis tools. Nucleic Acids Res 25, 4876-4882.

Tseng, T.-T., Gratwick, K. S., Kollman, J., Park, D., Nies, D. H., Goffeau, A. \& Saier, M. H., Jr (1999). The RND permease superfamily: an ancient, ubiquitous and diverse family that includes human disease and development proteins. $J \mathrm{Mol}$ Microbiol Biotechnol 1, 107-125.

Walmsley, A. R., Shaw, J. G. \& Kelly, D. J. (1992). The mechanism of ligand binding to the periplasmic $\mathrm{C}_{4}$-dicarboxylate binding protein (DctP) from Rhodobacter capsulatus. J Biol Chem 267, 8064-8072.

Winans, S. C. (1991). An Agrobacterium two-component regulatory system for the detection of chemicals released from plant wounds. Mol Microbiol 5, 2345-2350.

Young, G. B., Jack, D. L., Smith, D. W. \& Saier, M. H., Jr (1999). The amino acid/auxin:proton symport permease family. Biochim Biophys Acta 1415, 306-322.

Received 8 April 1999; revised 9 August 1999; accepted 16 August 1999. 